\title{
Prevalence of Oral Lesions in Anaemic Patients - A Hospital Based Study
}

\author{
Aathira.C.M ${ }^{1}$, Brundha. M.P² and Leslie Rani. $\mathrm{S}^{3}$ \\ ${ }^{1}$ Graduate student, Department of General Pathology, Saveetha dental college, \\ Saveetha Institute of Medical and Technical Sciences, Chennai, India \\ ${ }^{2}$ Associate Professor, Department of General Pathology, Saveetha Dental College, \\ Chennai, India Saveetha Institute of Medical and Technical Sciences Chennai, \\ Tamil Nadu, India \\ ${ }^{3}$ Tutor, Department of General Pathology, Saveetha Dental College, Saveetha Institute \\ of Medical and Technical Sciences, 162, Poonamallee High Road, Chennai-6000077 \\ Tamil Nadu, India
}

\section{ABSTRACT}

Oral lesion is an ulcer which is seen in the mucous membrane of the oral cavity. They may be seen individually or multiple lesions at the same time. It is presented with inflammation and secondary infection. The common oral lesions are stomatitis, erythema,candidiasis etc.The lesions can be evaluated by the sie location morphology, colour pain and duration.Patches that are red, white or mixed may indicate ulcerations.A white patch cannot be wiped off and so it may indicate leukoplakia and red patches are erythroplakia. The aim of this study is to analyse the oral manifestations presented by the patient's with hematological disorders like anaemia. Anaemic disorders are associated with orofacial signs and symptoms which is the major concern of this paper. It includes pallor, atrophic glossitis, angular stomatitis, dryness of mouth, burning sensation, ulcers. The patient's were checked for these manifestations in the oral cavity and assessed.20 anemic males and 20 anemic females aged between 30 years and 40 years were included in the study and were examined for any oral manifestations. the results showed more number of anemic patients are symptomatic and most common oral signs which are associated with anemia are pallor, oral aphthous ulcers and taste dysfunction. Eventhough atrophy is a common symptom we found a less significant association with anemia.

KEY WORDS: ANAEMIA, ORAL LESIONS, ANGULAR CHEILITIS, GLOSSITIS, PALLOR.

\section{INTRODUCTION}

A wide range of manifestation of diseases which causes damage to the internal organs are firstly shown in the

\section{ARTICLE INFORMATION}

*Corresponding Author: brundha.sdc@saveetha.com Received 5th August 2020 Accepted after revision 27th Sep 2020 Print ISSN: 0974-6455 Online ISSN: 2321-4007 CODEN: BBRCBA

Thomson Reuters ISI Web of Science Clarivate Analytics USA and Crossref Indexed Journal

\section{Clarivate
Analytics}

NAAS Journal Score 2020 (4.31) SJIF: 2020 (7.728)

A Society of Science and Nature Publication,

Bhopal India 2020. All rights reserved.

Online Contents Available at: http//www.bbrc.in/

Doi: http://dx.doi.org/10.21786/bbrc/13.8/7 oral cavity. Anaemia is a condition which can be either hereditary or acquired with an abnormal RBC (Henke and Pajonk, 2004). The major disorders observed commonly in the pro facial disorders are namely- anaemia, lymphoid disorder, bone marrow and immune deficiency and HIV virus (Long, Hlousek and Doyle, 1998). The most commonly affected region in the oral cavity is the oral mucous membrane followed by the periodontium. Upon examination of the mucous membrane and periodontitis, bleeding of gums and paleness in the mucous membrane are the commonest hematological disorders and treated in its early stage (Trandafir et al., 2016). Anaemia is most prevalent nowadays and it is caused due to decreased levels of red blood cells in an individual. It leads to

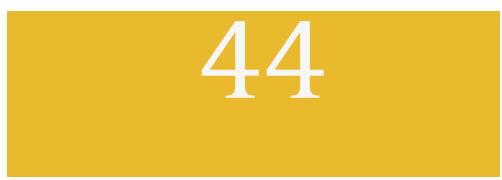


inability of the blood to supply oxygen to tissues resulting in ischaemia or necrosis of tissues (Anderson, Aronson and Jacobs, 1999).

The other common oral manifestations seen in the oral cavity are angular cheilitis, atrophic glossitis, pallor of mucous membrane etc. Angular cheilitis is the inflammation or cracks on the corners of the mouth. Atrophic glossitis is the depapillation of the tongue. All these are the manifestations seen in iron deficiency anemia patients. The basic serological tests performed are hematocrit value and haemoglobin estimation to diagnose the type of anaemia (Wickramasinghe, 2006). Iron deficiency anaemia is the most common type of anaemia seen in the majority of the population and shows the above mentioned oral manifestations. It also includes other manifestations apart from oral manifestations like koilonychia (spoon shaped nails), pagophagia and dysphagia.

Megaloblastic anaemia is another subclass which is caused due to impaired DNA synthesis which leads to increase in the size of RBCs and abnormalities in platelets and leukocyte morphology (Derossi and Raghavendra, 2003). The oral manifestations seen in patients with megaloblastic anaemia include glossitis, cheilitis, ulcers, candidiasis and pallor of mucous membrane (McFarlane et al., 1967).It also exhibits another condition called the geographic tongue and it affects a lesser percentage of population like 10-12\% (Sepuólveda et al., 2006) Aplastic anaemia often shows oral manifestations like multiple haemorrhages which is likely to be the first clinical sign (Sepuólveda et al., 2006). All hematological disorders produce common oral manifestations such as petechia, nose bleeding, post traumatic gingival hemorrhage etc.

A group of inherited disease that is caused due to defective synthesis of either alpha or beta chains of Hemoglobin is known as thalassemia which is a type of haemolytic anaemia, which is mostly asymptomatic (Clegg et al., 1968). It exhibits certain clinical features like chipmunk face, bossing of the skull etc (Modell, 1976).The other manifestations includes ulceration, candidiasis, viral infection, petechiae etc (Evans, Pogrel and Regezi, 2008) This research is an observational study conducted to analyse the most prevalent oral lesions seen in anaemia patients

\section{MATERIAL AND METHODS}

20 males and 20 females aged between 30 years and 40years, who visited the clinical laboratory of Saveetha dental college were included in the study and were examined for the oral manifestations. The pre medical and dental histories of the patients were collected. Oral cavity examinations are carried out by Mouth mirror and Probe. Sample is divided into two groups as Symptomatic and Asymptomatic despite the severity of anaemia. We checked for parameters like angular cheilitis, pallor of the mucous membrane, oral ulcers atrophy of the tongue and candidiasis.
Inclusion criteria: Patients with anaemia(Hemoglobin less than the normal for age and sex) was taken into the study and age limit set was 30-40 years. gender was not included.

Exclusion criteria: Patients not having anaemia and Anemia patients with chronic diseases were excluded from the study.

Table 1. The average value of the Participant's Haemoglobin, Haematocrit, RBC Count and MCV value are tabulated.

\begin{tabular}{|l|c|c|}
\hline Test & $\begin{array}{c}\text { Normal } \\
\text { range }\end{array}$ & $\begin{array}{c}\text { Patient's } \\
\text { mean value }\end{array}$ \\
\hline Haemoglobin & $12-15.5 \mathrm{~g} \%$ & $7.2 \mathrm{~g} \%$ \\
\hline Hematocrit & $36-45 \%$ & $23.4 \%$ \\
\hline RBC count & $3.90-5.03 \mathrm{cells} / \mathrm{cmm}$ & $1.63 \mathrm{cells} / \mathrm{cmm}$ \\
\hline MCV & $80-100 \mathrm{fl}$ & $144 \mathrm{fl}$ \\
\hline
\end{tabular}

Table 2. Frequency distribution of study population.

\section{Patients}

\begin{tabular}{|lll|r|}
\hline symptomatic & $\mathrm{N}$ & Valid & 22 \\
& & Missing & 0 \\
\hline asymptomatic & $\mathrm{N}$ & Valid & 18 \\
& & Missing & 0 \\
\hline
\end{tabular}

Figure 1: Bar chart showing the frequency of pallor among the symptomatic patients. 6 anemic patients are having pallor and 16 anemic patients don't have pallor.

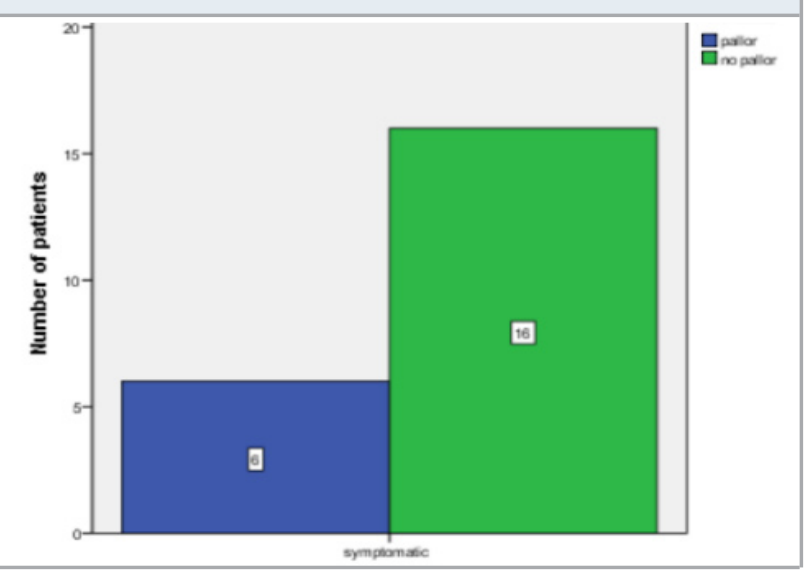

\section{RESULTS AND DISCUSSION}

Oral manifestations like pallor, stomatitis were observed in patients at the beginning of the disease. These were observed in all patients regardless of the duration or severity of anaemia. Anaemic patients have lower haemoglobin levels which means the oxygen carrying capacity of haemoglobin is low. Since iron is required 
for the oral epithelial cells and in case of iron deficiency anaemia the turnover is more rapid. Due to this it causes atrophy of the tongue (Neville et al., 2009). The basic serological tests performed are hematocrit value and haemoglobin estimation to diagnose the type of anaemia (Wickramasinghe, 2006). Iron deficiency anaemia is the most common type of anaemia seen in the majority of the population and shows the above mentioned oral manifestations. It also includes other manifestations apart from oral manifestations like koilonychia (spoon shaped nails), pagophagia and dysphagia.The role of dentists is a prime role as it is usually associated with oral manifestations. Due to an increase in the abnormal cells of the oral epithelium, it gives rise to a beefy red smooth erythematous tongue in these patients (Greenberg, 1981). Limitations of our study include, small sample size and non consideration of types of anemia. Future studies may be done to rectify with these limitations.

Figure 2: bar graph shows the frequency of ulcer among the symptomatic patients. 5 of them have ulcers and the remaining 17 of them not have ulcers.

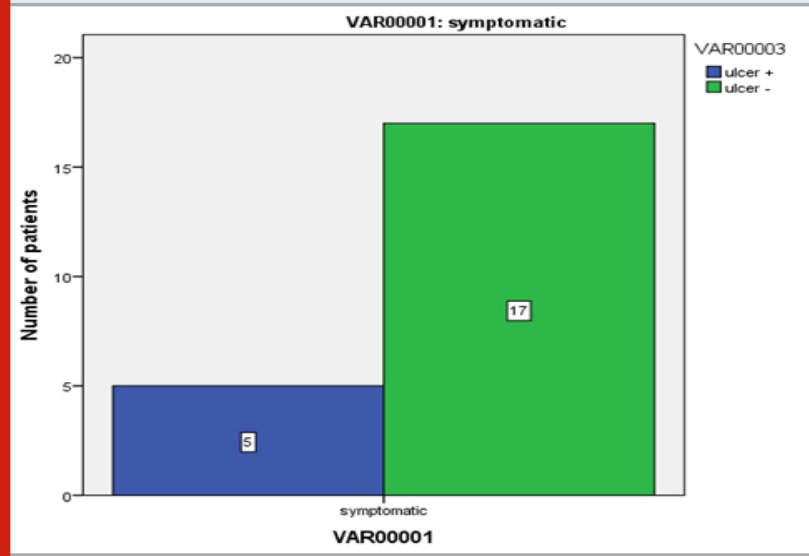

Figure 3: Bar graph shows the frequency of atrophy among the symptomatic patients where 8 of them have tongue atrophy and 14 of them don't have atrophy of tongue.

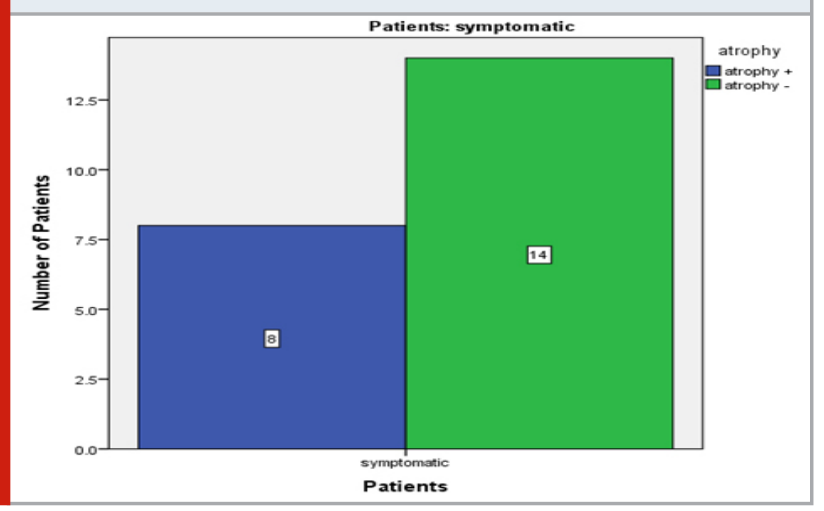

\section{CONCLUSION}

Within the limitations of the study we found that more number of anemic patients are symptomatic and most common oral signs which are associated with anemia are pallor, oral aphthous ulcers and taste dysfunction.
Figure 4: Bar graph shows the frequency of taste dysfunction among the symptomatic patients where 6 of them have taste dysfunction and 16 of them don't have taste dysfunction.

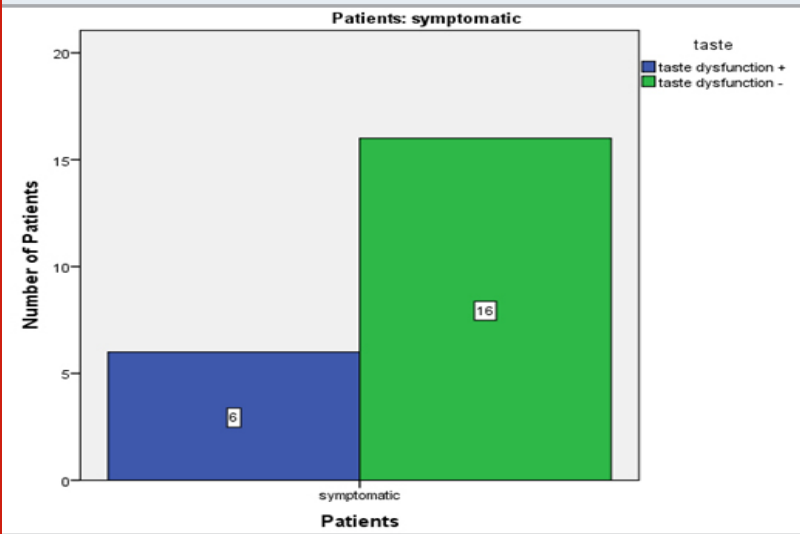

Table 2. Chi square analysis of the oral signs of anemia. This table shows that the signs like pallor, ulcers and taste dysfunction $[\mathrm{P}<0.05]$ are more commonly associated with anemia than atrophy[P $>0.05]$.

\begin{tabular}{|ll|r|r|r|r|}
\hline \multicolumn{7}{|c|}{ Test Statistics } \\
\hline Patients & & \multicolumn{1}{|c|}{ palor } & \multicolumn{1}{c|}{ ulcers } & atrophy & \multicolumn{1}{c|}{ taste } \\
\hline symptomatic & Chi-Square & $4.545^{\mathrm{a}}$ & $6.545^{\mathrm{a}}$ & $1.636^{\mathrm{a}}$ & $4.545^{\mathrm{a}}$ \\
& df & 1 & 1 & 1 & 1 \\
& Asymp. Sig. & 033 & 011 & 201 & .033 \\
\hline
\end{tabular}

Eventhough atrophy is a common symptom we found a less significant association with anemia.

\section{ACKNOWLEDGEMENTS}

We thank Saveetha Dental College for the support to carry out this study.

\section{Conflict of Interest: None to declare}

\section{REFERENCES}

Anderson, C., Aronson, I. and Jacobs, P. (1999) 'Erythrocyte Deformability is Reduced and Fragility increased by Iron Deficiency', Hematology, pp. 457-460. doi: 10.1080/10245332.1999.11746471.

Clegg, J. B. et al. (1968) 'Haemoglobin Synthesis in $\nabla$-Thalassaemia', Nature, pp. 664-668. doi: 10.1038/220664a0.

Derossi, S. S. and Raghavendra, S. (2003) 'Anemia', Oral surgery, oral medicine, oral pathology, oral radiology, and endodontics, 95(2), pp. 131-141.

Evans, W. W., Pogrel, M. A. and Regezi, J. A. (2008) 'Oral mucosal lesion associated with sickle cell disease', Oral Diseases, pp. 303-304. doi: 10.1111/j.1601-0825.1996. tb00243.x.

Greenberg, M. S. (1981) 'Clinical and histologic changes of the oral mucosa in pernicious anemia', Oral Surgery, Oral Medicine, Oral Pathology, pp. 38-42. doi: 
10.1016/0030-4220(81)90170-5

Henke, M. and Pajonk, F. (2004) 'Erythropoietin to treat anaemia in patients with head and neck cancer', The Lancet, p. 993. doi: 10.1016/s0140-6736(04)15804-2. Long, R. G., Hlousek, L. and Doyle, J. L. (1998) 'Oral manifestations of systemic diseases', The Mount Sinai journal of medicine, New York, 65(5-6), pp. 309-315. McFarlane, D. B. et al. (1967) 'Incidence of iron deficiency, with and without anaemia, in women in general practice', British journal of haematology, 13(5), pp. 790-796.

Modell, B. (1976) 'Management of thalassaemia major', British medical bulletin, 32(3), pp. 270-276.
Neville, B. W. et al. (2009) 'Preface', Oral and Maxillofacial Pathology, pp. ix-x. doi: 10.1016/b9781-4160-3435-3.50002-6.

Sepuólveda, E. et al. (2006) 'Oral manifestations of aplastic anemia in children', The Journal of the American Dental Association, pp. 474-478. doi: 10.14219/jada.archive.2006.0219.

Trandafir, L. M. et al. (2016) 'Marshall syndrome in a young child, a reality', Medicine, p. e5065. doi: 10.1097/ md.0000000000005065.

Wickramasinghe, S. N. (2006) 'Diagnosis of megaloblastic anaemias', Blood Reviews, pp. 299-318. doi: 10.1016/j. blre.2006.02.002. 